\title{
Flowering and Plant Development at the 38th Spanish Society of Genetics Congress, Murcia, 2011
}

\author{
Pedro Madrigal
}

Received: 26 October 2011/Accepted: 2 November 2011/Published online: 7 December 2011

(C) The Author(s) 2011. This article is published with open access at Springerlink.com

An outstanding prospective on current plant science research was presented when the Spanish Society of Genetics held its 38th biennial meeting in Murcia, the county seat of the fertile region of Murcia, Spain, from 21 to 23 September 2011. This conference traditionally brings together Spanish scientists from the Iberian Peninsula and Europe, along with renowned international speakers giving plenary lectures. The Congress, organized by the Department of Genetics of the University of Murcia, covered different fields of genetics: population genetics, human genetics, plant and animal biotechnology, microbial genetics, gene expression and epigenetics, cytogenetics, plant genetics, and genomics. The sessions on plant genetics, genomics, and plant biotechnology, chaired by José Luis Micol (Universidad Miguel Hernández, Elche), Roderic Guigó (CRAG, Barcelona), and Miguel Aranda (CEBAS-CSIC, Murcia), respectively, were particularly relevant for the field of plant growth regulation.

MADS-domain transcription factors, interacting in a combinatorial manner, are involved in controlling many principal aspects of plant development. Jose Luis Riechmann (Center for Research in Agricultural Genomics, Barcelona) presented recent results of a study on a master regulator of Arabidopsis flower development, the transcription factor APETALAl (APl), which is involved in the specification of floral meristems and the development of sepals and petals (Wellmer and Riechmann 2010; Ferrier and others 2011). Riechmann showed how APl controls a complex gene regulatory network that ensures and finetunes its own expression (Kaufmann and others 2010), acting as a hub in the network mediating the switch from

P. Madrigal $(\bowtie)$

Laboratory of Biometry, Institute of Plant Genetics, Polish Academy of Sciences, Strzeszyńska 34, 60-479 Poznań, Poland e-mail: pmad@igr.poznan.pl floral induction to flower formation. More than half of the transcription factors that have been identified as high-confidence $A P 1$ targets are uncharacterized, and new genome-wide binding studies are being performed to determine, for instance, the network controlled by $C A U$ LIFLOWER (CAL), another meristem identity gene activating floral homeotic pathways.

Thus, genomic technologies for identifying network components and regulatory interactions are crucial. On that matter, Joaquin Dopazo (Prince Felipe Research Centre, Valencia) presented "How to convert millions of reads into useful biological information" and the role of massive parallel-sequencing methodologies such as ChIP-seq and RNA-seq. Dopazo pointed out the difficulties for experimental researchers in finding user-friendly bioinformatics software, remarking on the importance of prioritization strategies to help to identify candidate genes.

The tomato ortholog of SHATTERPROOF MADS-box genes of Arabidopsis thaliana, TOMATO AGAMOUS-LIKE 1 (TAGL1), was found by Estela Giménez (IBMCP-UPV and University of Almeria), after carrying out gene overexpression and silencing experiments, to be a factor in the expression patterns of tomato genes involved in fruitripening processes and reproductive development (Giménez and others 2010). The essential role played by ARLEQUIN/ TAGL1 has been proven using genetic, molecular, and functional analyses of Arlequin (Alq) T-DNA tomato mutant, which showed that the corresponding gene acts as a coordinator of the reproductive processes in tomato plants.

The life cycle of a plant is determined by the natural environment, with flowering and germination synchronizing the period of plant growth. The session on plant genetics also included two different contributions on the model plant Arabidopsis. Carlos Alonso-Blanco (Centro Nacional de Biotecnología, Madrid) gave the talk "Molecular, genetic 
and ecological basis of natural variation for the initiation of flower development in Arabidopsis thaliana." AlonsoBlanco showed how vegetative growth and flower initiation are closely related by studying the genetic and molecular mechanisms underlying flowering time and rate of leaf production. He also suggested that natural selection may help to maintain phenotypic effects on both developmental processes (Méndez-Vigo and others 2010). Interestingly, the analysis of natural variation in flowering time can prove adaptations to different stress conditions or environments. Alonso-Blanco demonstrated how it is possible to analyze with Bayesian clustering-model algorithms the geographic distribution of natural genetic variation on the Iberian Peninsula (Picó and others 2008), and he explained how flowering-related traits are strongly associated with temperature and climatic factors (Méndez-Vigo and others 2011). Cecilia Oliver (Universidad Complutense, Madrid) analyzed the consequences of mutations of the gene $A R G$ ONAUTE4 (AGO4) involved in transcriptional silencing mechanisms (Zilberman and others 2003). The results indicate that repeat-associated small interfering RNAs (rasiRNAs) may play an important role in mitosis and meiosis processes.

To close the plant genetics session, the congress-opening plenary speaker Elliot Meyerowitz (California Institute of Technology, USA) offered one of the most highly acclaimed talks. Meyerowitz introduced the emerging field of computational morphodynamics in his talk entitled "Computational morphodynamics: Explicit models of genetic and cellular interactions in plant development." This field aims to complete the understanding of temporal and spatial changes occurring in plant growth by a combination of live imaging, image processing, and the development of theoretical models (Chickarmane and others 2010). Live imaging can be conducted with confocal laser scanning microscopy (Fig. 1), making possible the visualization of subcellular structures and even expressed fluorescently tagged proteins in transgenic plants. This new approach offers access to information from high-resolution optical imaging in a cell-by-cell fashion, capturing functional complexity in computational models.

The spiral phyllotactic pattern of leaves and flowers around the stem, generated by the shoot atypical meristem, involves chemical signaling conformed by the plant hormone auxin. A model based on differential equations was constructed for auxin-based patterning in the shoot, where nonuniform distributed efflux proteins directionally redirect auxin flux due to physical forces on the neighboring meristem cells, causing the phyllotaxis in a dynamic matter (Roeder and others 2011).

The session on plant biotechnology began with Pere Puigdomenech (Centre for Research in Agricultural Genomics, Barcelona) presenting the approaches taken in

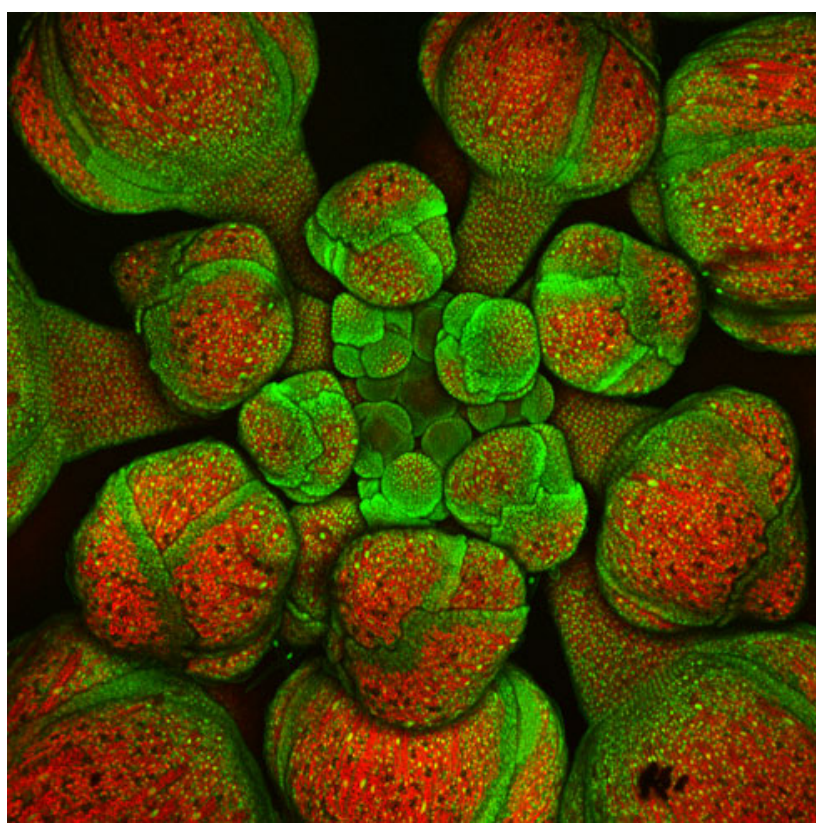

Fig. 1 Laser scanning confocal microscope image of an Arabidopsis thaliana shoot apex surrounded by developing flowers, which demonstrates the spiral phyllotactic pattern. Image provided by Elliot Meyerowitz (Caltech, USA) (Roeder 2010)

the sequencing of the Cucumis melo genome under the project "MELONOMICS: Development of genomic tools in Cucurbits, including the sequencing of the melon genome, and its application for breeding these crop species." Its main goal is to produce a draft sequence of the melon genome $(454 \mathrm{Mb})$ and its annotation. The team has reported the first physical map of a Cucurbitaceae species using a BAC library and several genetic maps (González and others 2010a), as well as chloroplast and mitochondrial genome sequences, the latter being the largest one known in plants (Rodríguez-Moreno and others 2011). The analyses revealed that some genome features are similar when compared against the genomic sequence of its close relative, the cucumber (González and others 2010b).

Also in melon, Veronica Truniger (Centro de Edafología y Biología Aplicada del Segura, Murcia) presented evidence that genetic resistance to Melon necrotic spot virus $(M N S V)$ is conferred by silencing the eukaryotic translation initiation factor 4E (elF4E), which hinders the correct formation of the translation initiation complex at the viral RNA ends (Nieto and others 2011).

The plant hormone abscisic acid (ABA) plays an essential role in stress physiology and controls growth and development. Pedro L. Rodriguez Egea (Instituto de Biología Molecular y Celular de Plantas, CSIC-UPV, Valencia) addressed the biotechnological implications of the ABA signaling pathway (Cutler and others 2010), where new alternatives to improve the response to stress caused by drought are partial inactivation of key repressors, such as the 
type $2 \mathrm{C}$ protein phosphatases ( $\mathrm{PP} 2 \mathrm{Cs}$ ), and the overexpression of activators as certain transcription factors regulated by SnRK2 kinases.

Leonor Ruiz García (IMIDA, Murcia) closed the session on plant biotechnology with the identification of quantitative trait loci (QTLs) for quality features in the table grape progeny 'Muscat Hamburg' $\times$ 'Sugraone'.

The gene expression and epigenetics session included two contributions in the plant science area. First, Teresa RoldánArjona (University of Cordoba) showed that the plant $3^{\prime}$ DNA phosphatase AtZDP participates in a later stage of the Arabidopsis REPRESSOR OF SILENCINGI (ROS1) active demethylation pathways in plants. This result is leading to a better comprehension of the role of DNA repair enzymes in modification of epigenetic patterns. Second, Cristina BarreroSicilia (Centro de Biotecnología y Genómica de Plantas, UPM-INIA, Madrid) approached the identification of cis-trans regulatory elements controlling the expression of genes encoding proteases involved in the germination process of Arabidopsis thaliana. A phylogenomic analysis of promoters from the orthologous gene AtCathB3 in 11 Brassicaceae species allowed for the identification of three highly conserved sequences during evolution. These sequences were used as bait for yeast one-hybrid screenings of an arrayed library of approximately 1,200 transcription factors from Arabidopsis thaliana, leading to the discovery of new interactors regulating this protease gene (Castrillo and others 2011).

It is equally important to note that a large number of interesting contributions were made within the presentations at the poster session, and that the best posters prizes were awarded to two plant genetics groups led by María Rosa Ponce (Universidad Miguel Hernández, Elche) and Rafael Lozano (Universidad de Almería). Moreover, during the course of the Congress, the Spanish Society of Genetics and Pryconsa Foundation recognized Professor Enrique Cerdá Olmedo (University of Seville) for his work in the category of basic genetics research, and Professor Manel Esteller Badosa (University of Barcelona) for his applied genetics research with the National Genetics Awards 2011.

Acknowledgments The author gratefully acknowledges José Luis Micol, Monserrat Elías, Paweł Krajewski, and Santiago Torres for helpful comments, and the financial support of the EU Marie Curie ITN SYSFLO (Agreement Number 237909).

Open Access This article is distributed under the terms of the Creative Commons Attribution Noncommercial License which permits any noncommercial use, distribution, and reproduction in any medium, provided the original author(s) and source are credited.

\section{References}

Castrillo G, Turck F, Leveugle M, Lecharny A, Carbonero P, Coupland G, Paz-Ares J, Oñate-Sánchez L (2011) Speeding cis-trans regulation discovery by phylogenomic analyses coupled with screenings of an arrayed library of Arabidopsis transcription factors. PLoS ONE 6:e21524

Chickarmane V, Roeder AH, Tarr PT, Cunha A, Tobin C, Meyerowitz EM (2010) Computational morphodynamics: a modeling framework to understand plant growth. Annu Rev Plant Biol 61:65-87

Cutler SR, Rodriguez PL, Finkelstein RR, Abrams SR (2010) Abscisic acid: emergence of a core signaling network. Annu Rev Plant Biol 61:651-679

Ferrier T, Matus JT, Jin J, Riechmann JL (2011) Arabidopsis paves the way: genomic and network analyses in crops. Curr Opin Biotechnol 22:260-270

Giménez E, Pineda B, Capel J, Antón MT, Atarés A, Pérez-Martín F, García-Sogo B, Angosto T, Moreno V, Lozano R (2010) Functional analysis of the Arlequin mutant corroborates the essential role of the ARLEQUIN/TAGL1 gene during reproductive development of tomato. PLoS ONE 5:e14427

González VM, Garcia-Mas J, Arús P, Puigdomènech P (2010a) Generation of a BAC-based physical map of the melon genome. BMC Genomics 11:339

González VM, Benjak A, Hénaff EM, Mir G, Casacuberta JM, Garcia-Mas J, Puigdomènech $\mathrm{P}$ (2010b) Sequencing of $6.7 \mathrm{Mb}$ of the melon genome using a BAC pooling strategy. BMC Plant Biol 10:246

Kaufmann K, Wellmer F, Muiño JM, Ferrier T, Wuest SE, Kumar V, Serrano-Mislata A, Madueño F, Krajewski P, Meyerowitz EM, Angenent GC, Riechmann JL (2010) Orchestration of floral initiation by APETALA1. Science 328:85-89

Méndez-Vigo B, de Andrés MT, Ramiro M, Martínez-Zapater JM, Alonso-Blanco CA (2010) Temporal analysis of natural variation for the rate of leaf production and its relationship with flowering initiation in Arabidopsis thaliana. J Exp Bot 61:1611-1623

Méndez-Vigo B, Picó XF, Ramiro M, Martínez-Zapater JM, AlonsoBlanco C (2011) Altitudinal and climatic adaptation is mediated by flowering traits and FRI, FLC and PhyC genes in Arabidopsis thaliana. Plant Physiol 157. doi:10.1104/pp.111.183426

Nieto C, Rodríguez-Moreno L, Rodríguez-Hernández AM, Aranda MA, Truniger V (2011) Nicotiana benthamiana resistance to non-adapted melon necrotic spot virus results from an incompatible interaction between virus RNA and translation initiation factor 4E. Plant J 66:492-501

Picó FX, Méndez-Vigo B, Martínez-Zapater JM, Alonso-Blanco C (2008) Natural genetic variation of Arabidopsis thaliana is geographically structured in the Iberian peninsula. Genetics 180:1009-1021

Rodríguez-Moreno L, González VM, Benjak A, Martí MC, Puigdomènech P, Aranda MA, Garcia-Mas J (2011) Determination of the melon chloroplast and mitochondrial genome sequences reveals that the largest reported mitochondrial genome in plants contains a significant amount of DNA having a nuclear origin. BMC Genomics 12:424

Roeder AH (2010) PLoS Biology Issue Image. PLoS Biol 8(5):ev08.i05. Available at http://www.plosbiology.org/article/ info:doi/10.1371/image.pbio.v08.i05

Roeder AH, Tarr PT, Tobin C, Zhang X, Chickarmane V, Cunha A, Meyerowitz EM (2011) Computational morphodynamics of plants: integrating development over space and time. Natl Rev Mol Cell Biol 12:265-273

Wellmer F, Riechmann JL (2010) Gene networks controlling the initiation of flower development. Trends Genet 26:519-527

Zilberman D, Cao X, Jacobsen SE (2003) ARGONAUTE4 control of locus-specific siRNA accumulation and DNA and histone methylation. Science 299:716-719 